Crime, Histoire \& Sociétés / Crime, History \& Societies

Vol. 21, n² | 2017

L'histoire de la criminalité et de la justice pénale : propositions de recherche pour le $21^{\mathrm{e}}$ siècle

\title{
Criminal Justice History in Canada: Some Thoughts on Future Developments
}

\section{Donald Fyson}

\section{(2) OpenEdition \\ Journals}

Electronic version

URL: https://journals.openedition.org/chs/1862

DOI: $10.4000 /$ chs. 1862

ISSN: 1663-4837

\section{Publisher}

Librairie Droz

\section{Printed version}

Date of publication: 31 December 2017

Number of pages: 173-182

ISSN: $1422-0857$

\section{Electronic reference}

Donald Fyson, "Criminal Justice History in Canada: Some Thoughts on Future Developments", Crime, Histoire \& Sociétés / Crime, History \& Societies [Online], Vol. 21, n² | 2017, Online since 19 July 2020, connection on 07 December 2022. URL: http://journals.openedition.org/chs/1862 ; DOI: https:// doi.org/10.4000/chs. 1862 


\title{
Criminal Justice History in Canada: Some Thoughts on Future Developments ${ }^{1}$
}

\author{
Donald Fyson
}

\begin{abstract}
A ssiduous readers of Crime, Histoire \& Sociétés over the last two decades may be forgiven for thinking that Canada, and especially Canada outside of Quebec, is a bit of a backwater for research on crime and criminal justice history. After all, among 200 or so full articles published in the journal, only four have concerned Canada, mostly on Quebec; and of something over 300 books reviewed, only seven address crime and criminal justice in Canada, all essentially on Quebec. In fact, crime and criminal justice history is alive and well in Canada as a whole, just as it was in 1996 when Jim Phillips published what is still the most recent general historiographical overview of the field ${ }^{2}$. Since Phillips' overview, there have been well over a thousand scholarly monographs, articles, theses, and so on produced, covering all of Canada's regions, in English and in French ${ }^{3}$. Or from another perspective, in a survey of four of Canada's main history journals since 1996, a little under a tenth of articles dealt wholly or in significant part with crime and criminal justice ${ }^{4}$. Russell Smandych and Bryan Hogeveen's observation in 1999 that Canadian criminal justice history was "conspicuously underdeveloped", "conspicuously marginalized", and not "accepted into the mainstream of Canadian historiography" thus now seems to be less evident ${ }^{5}$, even though the extent of work on Canada still evidently pales in comparison with that on larger societies such as the United States, Great Britain, or France. Furthermore, as any reader of this historiography can appreciate, Canadian scholars of criminal justice history have much to offer not only to Canadian history itself, but also to the international history of crime and criminal justice.
\end{abstract}

My intent in this brief article is not to provide a historiographical analysis of

My thanks to Jim Phillips, Carolyn Strange and Blaine Baker for their helpful comments.

2 Phillips (1996, p.163-199). There have been a few more narrowly focused historiographical overviews, including English (2005, p.19-38) and Bumsted (2005, p.39-45); G. Blaine Baker (2013, p.3-95) and Donald Fyson (2014, p.412-432).

3 This figure is no doubt largely underestimated, as it is based on my own research using standard bibliographical tools; masters' theses and book chapters are likely areas of weakness. Note that in the limited examples given below, I have largely limited myself to published monographs, leaving aside articles, books chapters and unpublished theses.

4 Canadian Historical Review, Histoire sociale/Social History, Revue d'histoire de l'Amérique française and Labour/Le Travail. In all, about 8 percent of the 1100 or so articles surveyed concerned crime and criminal justice.

5 Smandych and Hogeveen (1999, p.191 and 199). As one indicator, in a sample of a little over 200 theses in Canadian crime and criminal justice history since 1996, constituted from a systematic search in ProQuest Dissertations \& Theses, a little under two thirds had been done within history programs, as compared to about $15 \%$ in criminology, $10 \%$ in law and 5\% in sociology. Among doctoral theses alone, the contribution of history programs was slightly higher, at about two thirds. 
this production, as Phillips did in 1996. Instead, concentrating on publications since then, I will try to identify which areas seem particularly strong and of interest to Canadian and international scholars, and suggest a few which might warrant further development. My overview has no pretentions whatsoever of being comprehensive, nor in any way offering an overall prospectus for future development of the field; at best, I hope to stimulate reflection and discussion.

\section{SYNTHESIS AND SURVEY}

One issue that makes this sort of exercise particularly difficult in Canada, in comparison with the United States, Great Britain, or France, is that there is still a dearth of substantial historical syntheses in the field, both general syntheses of the history of crime and criminal justice, and regional or broad thematic surveys. There is as yet no satisfying general, long-term survey of the history of crime and criminal justice in Canada or in any of its major regions ${ }^{6}$, although a survey of Canadian legal history currently being completed by Jim Phillips, Phillip Girard and Blake Brown will go a long way to filling the gap. Nor are there many studies of long-term trends in criminalization, in part because positivist criminologists in Canada have tended not to extend their quantitative analyses back before the advent of the current Canadian system of crime reporting in the 1960s, but also because many historians have focussed more on case studies than on broad quantitative analyses ${ }^{7}$. As for the few recent broad thematic surveys, the best to date is the recent book by Greg Marquis on the history of policing in Canada, to which one might add Marcel Martel's overview of the history of a selection of vices in Canada ${ }^{8}$. Other broad thematic syntheses tend to be limited to narrower periods ${ }^{9}$. While authors embarking on such enterprises inevitably open themselves to criticism from area specialists, they are of great use both to students and to criminal justice scholars less well-versed in Canadian history. We very much need a general history of women, crime and criminal justice in Canada; of Indigenous peoples' conceptions of and relationship to crime and criminal law; of violence and violent crime; of prisons and imprisonment; all areas which have been extensively explored in more focussed studies. These sorts of syntheses also encourage the sorts of big-picture conclusions which are of particular interest to an international readership.

\section{PLACE AND TIME}

One reason for the lack of synthesis is that Canadian history as a whole is a highly fragmented field, both by region and by time period, a reflection of the country's origins in a series of disparate French and English colonies and Indigenous lands forcibly

\footnotetext{
6 There are some limited to specific, usually earlier, periods; for example, Jerry Bannister (2003).

7 One exception is Fyson (2005, p.85-119). There have also been more focussed studies of specific crimes, such as Gartner (1995, p.186-222). For a critical view of the usefulness of such analyses, see Backhouse (2008, p.7-8).

8 See Marquis (2016) and Martel (2014).

$9 \quad$ See Boritch (1997) and Strange and Loo (1997).
} 
welded together in an only partially successful exercise in nation-building. It is thus no surprise that the same holds for Canadian crime and criminal justice history, with the bulk of scholarly endeavour focussed on particular regions, provinces or cities, although there are also many pan-Canadian studies, and with far more production on more populated regions such as central Canada or British Columbia than on the Atlantic region or the North. This fragmentation makes the field particularly difficult to grasp by those without a good knowledge of the particularities of Canada's internal socio-political configuration.

The most obvious example of the effects of this fragmentation is Quebec. Most Quebec scholars, including myself, define their "national" space as Quebec, and work on Quebec; almost none work on Canada outside of Quebec, and there are few comparative studies of crime and criminal justice in Quebec and elsewhere in Canada ${ }^{10}$. Furthermore, the international networks of Quebec criminal justice historians tend to be far more with francophone countries such as France and Belgium, meaning that much of the comparative work concerning Quebec tends to be with these countries. This is partly due to language issues (francophone Quebec scholars are often more comfortable in their own language; some English-Canadian scholars seem to ignore work in French) and to the internal structuring of academic work (Quebec academics have their own scholarly societies, journals, and so on). It is also reflected in the fact that while there are indeed a number of pan-Canadian studies of phenomena such as political policing, gambling, or drug offences, which include Quebec in their discussions ${ }^{11}$, others explicitly or implicitly limit themselves to "English" Canada (i.e., Canada outside of Quebec) $)^{12}$. While a bit of a bromide in Canadian historiography, it bears repeating that explicit comparisons between Quebec and other Canadian provinces or regions can only enrich the historiographies of both. At any rate, even among pan-Canadian studies, only a few place comparison between Canada's different regions at the heart of their analysis ${ }^{13}$. This despite the analytical potential of such an approach, given Canada's federal nature (criminal law being a federal responsibility, but criminal justice administration falling to the provinces) and diverse social composition. With this relative lack of explicit internal comparison, it is not surprising that international comparison and transnational approaches also remain limited, beyond the usual comparative contextualization that most historians do; one promising avenue is the growing body of work on crime and criminal justice in the Canada-US borderlands ${ }^{14}$.

Again as in Canadian history as a whole, "place" in Canada has also often tended to mean large urban centers. With the exception of work on Western Canada and on Indigenous peoples, investigation into crime and criminal justice in rural Canada is seriously underdeveloped. For example, in Quebec, most studies of crime and criminal justice history after the 1830s have concentrated on Montreal, and to a lesser extent, Quebec City; there are a few studies of smaller towns such as Trois-Rivières

\footnotetext{
10 This is also the case for contemporary criminology: see Dupont (2011, p.31-54).

11 Hewitt (2002); Morton (2003); Martel (2006).

12 Sangster (2002).

13 Brown (2009).

14 For explicitly comparative history: Niget (2009) and Graybill (2007). On the Canada-US borderlands: Miller (2016) and Moore (2014).
} 
or Sherbrooke; but almost nothing on rural areas. Since the majority of Canadians lived in rural areas or small towns well into the twentieth century, this means that the historiographical representation of crime and criminal justice in Canada reflects the experiences of a minority of the population ${ }^{15}$.

As for chronological coverage, Phillips noted in 1996 that research on crime and criminal justice history in Canada had concentrated on two specific periods, the French régime up to the middle of the eighteenth century and Canada from the midnineteenth to the early twentieth centuries ${ }^{16}$. The period from the 1960s onwards had also been extensively explored by criminologists, although often without much of a historical perspective. Since then, most of these gaps have been covered at least in part. We now know a great deal more about the period from the mid-eighteenth to the mid-nineteenth centuries, with substantial work on most of the major preConfederation colonies ${ }^{17}$. The twentieth century up to and including World War II has also been increasingly explored, and work on the period after the war is being filled in. Historians still however seem to be reluctant to take on crime in the post1960 era, although there are excellent studies of specific themes ${ }^{18}$.

\section{PROCESSES OF CRIMINALIZATION}

In recent decades, crime and criminal justice history in Canada has largely been the work of historians and other scholars with research agendas driven by critical and politically progressive perspectives, intent on uncovering and denouncing the power imbalances and injustices that have underlain Canadian society ${ }^{19}$. As a result, there has been extensive and excellent work on the criminalization of what might be termed "minority groups" very evidently targeted or mistreated by the law, including women, Indigenous peoples, other racialized minorities, and those who deviate from the sexual "norm" such as homosexuals. This was already the case in 1996 for work on women and criminal justice, with multiple studies of issues such as prostitution, abortion, and sexual assault, and a robust use of feminist theory; this work continues, with gender being perhaps the most commonly used category of analysis in the field ${ }^{20}$. The last two decades have also seen detailed critical scholarship on Indigenous peoples and European criminal law, often flowing from current political struggles for the recognition of Indigenous rights. This has been one of the most innovative fields in Canadian criminal justice history, with its mix of traditional knowledge, oral history, post-colonial and critical legal theory, and so on, and may be particularly useful for international scholars ${ }^{21}$. There has also been quite a bit of work on the criminalization of Blacks and some on that of Asians, which has powerfully

\footnotetext{
15 A recent exception is Craven (2014).

16 In an earlier 1991 historiographical piece, Phillips chose not to discuss the period after 1920 at all, since "too little work has been done on more recent decades". Phillips (1991, p.68).

17 For example, Bannister (2003); Fyson (2006); Murray (2002); Gibson (2015).

18 Whitaker et al. (2012).

19 As is also the case for Canadian criminology: see Martel, Hogeveen and Woolford (2006, p.633-646).

20 Recent examples include Glasbeek (2014) and Poutanen (2015).

21 Wicken (2012).
} 
underscored the very evidently racist past of Canada's criminal law and criminal justice system; along with the work on Indigenous peoples, these studies have made it impossible to ignore race as a fundamental category of analysis in Canadian criminal justice history ${ }^{22}$. However, there has been less work on the relationship of European immigrant groups to crime and criminal justice, with the exception of a considerable body of scholarship on political policing and on the internment and deportation of "undesirable" aliens ${ }^{23}$. Thus, there have been scattered studies on the criminalization of the Irish in the nineteenth century, but with a few exceptions, little on twentiethcentury immigrant groups such as Italians or Jews. Furthermore, although francophone Canadians constituted the most numerous "minority" group in Canada, they are not problematized as such within Quebec (in part because of the relative isolation and internal focus of Quebec scholarship), while outside of Quebec, they have often been ignored. Finally, while the criminalized population was predominately male, there are only a few studies of crime and criminal justice that explicitly place masculinity at the heart of the analysis, an approach that would greatly benefit studies of crime, policing, judging, and punishing and also help link Canadian criminal justice history to international trends ${ }^{24}$.

\section{CRIME}

Given the concentration of Canadian crime and criminal justice historians on progressive issues, it is unsurprising that reading the recent historiography, one might think that historically, Canadian crime consisted largely of a relatively limited subset of criminalized behaviours, including prostitution, sexual assault, homosexuality, riot, abortion, alcohol and drug consumption, spousal and family violence, vagrancy, political radicalism, and so on. Far less attention has been paid to criminalized behaviours which do not so easily fit into this mould. Hence, most types of ordinary violence, including homicides as a whole, are little studied, except specific types such as violence against women, or specific individual cases. Similarly, property crime of all types, from theft and robbery to fraud, has been the object of only a scant handful of studies, despite both its prevalence and its impact on respectable notions of security ${ }^{25}$. This relative lack of attention also applies to white collar crime in general, which has the unfortunate effect of understating the criminality of the middle classes, who in the historiography come across as those who enforce the laws, not those who break them. In a similar vein, Canadian scholars have largely neglected the study of regulatory offences, such as infractions of municipal bylaws and provincial statutes, with the most telling example being traffic offences such as speeding and parking. As elsewhere in the West, these increasingly dominated penal offences in Canada in the twentieth century, attracting expanding policing and judicial resources, and more importantly, fundamentally altering the relationship of "law-abiding"

\footnotetext{
22 Walker (2010) and Mawani (2009).

23 Whitaker et al. (2012); Kordan (2002); Molinaro (2017).

24 The most extensive work in this regard has been by those studying youth justice; see for example Hogeveen (2005, p.37-69) and Myers (2005, p.383-414).

25 Bisha $(2015$, p.571-581).
} 
Canadians to the police and the courts as well as providing ample scope for police and judicial corruption. Nevertheless, this phenomenon is almost completely ignored in the Canadian historiography ${ }^{26}$. While it is essential to continue the study of those behaviours which have thus far mainly attracted the attention of researchers, these other areas also deserve more study.

\section{LAW AND JUSTICE}

As with criminalized behaviours, there is also considerable imbalance in the aspects of the criminal law and the criminal justice system that have been studied, leaving large gaps that warrant being filled. Phillips noted in 1996 that the history of criminal law itself had been little studied in any comprehensive fashion. Since then, there have been a number of studies of changes to the Canadian Criminal Code following its adoption in $1892^{27}$. However, there has been only scattered attention paid to criminal law change in the half-century or so preceding the Criminal Code, a period when the criminal law was in theory moving from colonial plurality to national uniformity. As well, the Criminal Code constitutes only one part of Canada's penal law; as noted above, relatively little has been done on low law, such as provincial statutes and local bylaws, other than piecemeal studies within focused analyses of issues such as prostitution, alcohol regulation or game laws.

The study of criminal justice institutions themselves has also remained a secondary field. Just as in 1996, police history remains under-developed, apart from the large body of work on the Royal Canadian Mounted Police. For instance, although we now have scattered studies of policing in most of Canada's larger cities, there are few studies of rural and small-town policing; and there is little on the involvement of minority groups such as Indigenous peoples in policing ${ }^{28}$. While the broad contours of Canada's criminal courts are well-known, and they have been relatively well examined up to the beginning of the twentieth century, our knowledge of their operation and personnel (judges and court officials) in the twentieth century remains very patchy, apart from youth justice ${ }^{29}$. The role of women in the criminal justice system might be further explored: not just as judges, policewomen and attorneys, but also in subordinated but essential roles such as stenographers or jailer's wives. The criminal practice of lawyers is also virtually unknown, nor has there been much written on the teaching of criminal law in law schools. Finally, studies of prisons remain focussed in large part on the penitentiary system, to which has been added a considerable body of work on youth incarceration facilities such as reform and industrial schools. Both of these fields are key to understanding the carceral phenomenon in Canada, and the literature is usually firmly anchored in the broader international context. There is

26 This is reflected in Marquis' survey of police history in Canada, which acknowledges that "Traffic and other bylaw infractions $[\ldots]$ came to dominate police formal interactions with the public" but devotes only a single paragraph to them. See Marquis (2016).

27 Cellard and Pelletier (1998, p.261-303); Kimmel and Robinson (2001, p.147-166).

28 Swainger (2003, p.198-223); Sawaya (2012).

29 Myers (2006). 
however only scattered work on the local jails where most prisoners ended up ${ }^{30}$, and even less on imprisonment in the police lock-up cells that proliferated from the late nineteenth century onwards.

\section{CONCLUSION}

These are only a few limited observations on the state of crime and criminal justice history in Canada and potential areas for development. There are many others. For example, analyses of punishment and violence tend to be informed very largely by Foucauldian approaches, with relatively little attention paid to Norbert Elias' theories of the "civilizing process"; as some scholars have pointed out, these might bring a useful alternate perspective to the analysis, and also bring Canadian scholarship more in line with international trends ${ }^{31}$. Or again, recent work on the representation of crime and justice in literature and in film points to a very largely underdeveloped field of inquiry; the visual imagery of crime and criminal justice in particular has received little attention ${ }^{32}$. Finally, while some professional Canadian historians have set themselves to the informed popularization of crime and criminal justice history in Canada ${ }^{33}$, this space is largely left to others, and as a result there is a strong sensationalist and largely uncritical bent in many popularizing endeavours, as a recent study of prison museums in Canada has shown ${ }^{34}$. One can only hope that in another twenty years' time, many of the gaps noted in this text will have been filled in, and that Canadian criminal justice history will have moved beyond its current, largely national boundaries.

Donald Fyson

Université Laval

Département des sciences historiques

Quebec City, Quebec, Canada donald.fyson@hst.ulaval.ca

\section{BIBLIOGRAPHY}

Backhouse, C. (2008) Carnal Crimes: Sexual Assault Law in Canada, 1900-1975, Toronto: Osgoode Society for Canadian Legal History and Irwin Law.

Baker, G.B. (2013) Introduction: Quebec and the Canadas, 1760 to 1867: A Legal Historiography, in Baker, G.B., Fyson, D. (Eds.), Essays in the History of Canadian Law. Volume XI: Quebec and the Canadas, Toronto: Osgoode Society for Canadian Legal History and University of Toronto Press, p.3-95.

\footnotetext{
Oliver (1998); Fyson (2016 p.15-103).

31 Strange (2001, p.343-385).

32 Strange and Loo (2004); Gagnon (2016); Kohm et al. (2017).

33 For example, the Great Unsolved Mysteries in Canadian History website http://canadianmysteries.ca.

34 Walby and Piché (2015, p.475-502).
} 
Bannister, J. (2003) The Rule of the Admirals: Law, Custom, and Naval Government in Newfoundland, 1699-1832, Toronto: University of Toronto Press.

Bisha, T. (2015) The Beast and the Dwelling House: On Sleeping Safely in Early Upper Canada, Anthropologica, 57, 2, p.571-581.

Boritch, H. (1997) Fallen Women: Female Crime and Criminal Justice in Canada, Toronto: Nelson.

Brown, R.B. (2009) A Trying Question: The Jury in Nineteenth-Century Canada, Toronto: Osgoode Society for Canadian Legal History and University of Toronto Press.

Bumsted, J.M. (2005) The Legal Historiography of Prince Edward Island, in English, C. (Ed.), Essays in the History of Canadian Law. Volume IX: Two Islands, Newfoundland and Prince Edward Island, Toronto: Osgoode Society for Canadian Legal History and University of Toronto Press, p.39-45.

Cellard, A. and Pelletier, G. (1998) Le Code criminel canadien 1892-1927: étude des acteurs sociaux, Canadian Historical Review, 79, 2, p.261-303.

Craven, P. (2014) Petty Justice: Low Law and the Sessions System in Charlotte County, New Brunswick, 1785-1867, Toronto: Osgoode Society for Canadian Legal History and University of Toronto Press.

Dupont, B. (2011) The Dilemmas of "Doing” Criminology in Québec: Curse or Opportunity?, in Doyle, A. and Moore, D. (Eds.), Critical Criminology in Canada: New Voices, New Directions, Vancouver: UBC Press, p.31-54

English, C. (2005) The Legal Historiography of Newfoundland, in English, C. (Ed.), Essays in the History of Canadian Law. Volume IX: Two Islands, Newfoundland and Prince Edward Island, Toronto: Osgoode Society for Canadian Legal History and University of Toronto Press, p.19-38.

Fyson, D. (2005) The Judicial Prosecution of Crime in the Longue Durée: Quebec, 1712-1965, in Fecteau, J-M and Harvey, J. (Eds.), La régulation sociale entre l'acteur et l'institution: pour une problématique historique de l'interaction, Québec: Presses de l'Université du Québec, p.85-119.

Fyson, D. (2006) Magistrates, Police, and People: Everyday Criminal Justice in Quebec and Lower Canada, 1764-1837, Toronto: Osgoode Society for Canadian Legal History and University of Toronto Press.

Fyson, D. (2014) Between the Ancien Régime and Liberal Modernity: Law, Justice and State Formation in Colonial Quebec, 1760-1867, History Compass, 12, 5, p.412-432.

Fyson, D. (2016) Prison Reform and Prison Society: The Quebec Gaol, 1812-1867, in Blair, L., Donovan, P. and Fyson, D., From Iron Bars to Bookshelves: A History of the Morrin Centre, Montreal: Baraka Books, p.15-103.

Gagnon, A. (2016) La communauté du dehors. Imaginaire social et crimes célèbres au Québec (XIX ${ }^{e}-X X^{e}$ siècle), Montréal: Presses de l’Université de Montréal.

Gartner, R. (1995) Homicide in Canada, in Ross, J.I. (Ed.), Violence in Canada: Sociopolitical Perspectives, Toronto: Oxford University Press, p.186-222.

Gibson, D. (2015) Law, Life, and Government at Red River, Montreal: McGill-Queen's University Press.

Glasbeek, A. (2014) Feminized Justice: The Toronto Women's Court, 1913-34, Vancouver: UBC Press, 2014. 
Graybill, A.R. (2007) Policing the Great Plains: Rangers, Mounties, and the North American Frontier, 1875-1910, Lincoln: University of Nebraska Press.

Hewitt, S. (2002) Spying 101: The RCMP's Secret Activities at Canadian Universities, 19171997, Toronto: University of Toronto Press.

Hogeveen, B. (2005) The Evils with Which We are Called to Grapple: Élite Reformers, Eugenicists, Environmental Psychologists, and the Construction of Toronto's WorkingClass Boy Problem, 1860-1930, Labour/Le Travail, 5, p.37-69.

Kimmel, D, and Robinson, D.J. (2001) Sex, Crime, Pathology: Homosexuality and Criminal Code Reform in Canada, 1949-1969, Canadian Journal of Law and Society, 16, 1, p.147-166.

Kohm, S.A., Bookman, S. and Greenhill, P. (2017) Screening Justice: Canadian Crime Films, Culture and Society, Halifax: Fernwood Publishing.

Kordan, B.S. (2002) Enemy Aliens, Prisoners of War: Internment in Canada During the Great War, Montreal: McGill-Queen's University Press.

Marquis, G. (2016) The Vigilant Eye: Policing Canada From 1867 to 9/11, Black Point: Fernwood Publishing.

Martel, M. (2006) Not this Time: Canadians, Public Policy, and the Marijuana Question, 1961 1975, Toronto: University of Toronto Press.

Martel, M. (2014) Canada the Good: A Short History of Vice since 1500, Waterloo: Wilfrid Laurier University Press.

Martel, J., Hogeveen, B. and Woolford, A. (2006) The State of Critical Scholarship in Criminology and Socio-Legal Studies in Canada, Canadian Journal of Criminology and Criminal Justice, 48, 5, p.633-646.

Mawani, R. (2009) Colonial Proximities: Crossracial Encounters and Juridical Truths in British Columbia, 1871-1921, Vancouver: UBC Press.

Miller, B. (2016) Borderline Crime: Fugitive Criminals and the Challenge of the Border, 18191914, Toronto: Osgoode Society for Canadian Legal History and University of Toronto Press.

Molinaro, D.G. (2017) An Exceptional Law: Section 98 and the Emergency State, 1919-1936, Toronto: University of Toronto Press.

Moore, S.T. (2014) Bootleggers and Borders: The Paradox of Prohibition on a Canada-U.S. Borderland, Lincoln: University of Nebraska Press.

Morton, S. (2003) At Odds: Gambling and Canadians, 1919-1969, Toronto: University of Toronto Press.

Murray, D.R. (2002) Colonial Justice: Justice, Morality and Crime in the Niagara District, 1791-1849, Toronto: Osgoode Society for Canadian Legal History and University of Toronto Press.

Myers, T. (2005) "Embodying Delinquency: Boys" Bodies, Sexuality, and Juvenile Justice History in Early-Twentieth-Century Quebec, Journal of the History of Sexuality, 14, 4, p.383-414.

Myers, T. (2006) Caught: Montreal's Modern Girls and the Law, 1869-1945, Toronto: University of Toronto Press.

Niget, D. (2009) La naissance du tribunal pour enfants: une comparaison France-Québec (1912-1945), Rennes: Presses universitaires de Rennes. 
Oliver, P. (1998) “Terror to Evil-Doers": Prisons and Punishment in Nineteenth-Century Ontario, Toronto: Osgoode Society for Canadian Legal History and University of Toronto Press.

Phillips, J. (1991) The History of Canadian Criminal Justice, 1750-1920, in Gladstone, J. et al. (Eds.), Criminology: A Reader's Guide, Toronto: University of Toronto Press.

Phillips, J. (1996) Crime and Punishment in the Dominion of the North: Canada from New France to the Present, in Emsley, C. and Knafla, L.A. (Eds.), Crime History and Histories of Crime: Studies in the Historiography of Crime and Criminal Justice in Modern History, Westport: Greenwood Press, p.163-199.

Poutanen, M.A. (2015) Beyond Brutal Passions: Prostitution in Early Nineteenth-Century Montreal, Montreal: McGill-Queen's University Press.

Sangster, J. (2002) Girl Trouble: Female Delinquency in English Canada, Toronto: Between the Lines.

Sawaya, J.-P. (2012) Au nom de la loi, je vous arrête! Les Amérindiens du Québec et la Dominion Police, 1880-1920, Québec: Septentrion.

Smandych, R. and Hogeveen, B. (1999) On the Fragmentation of Canadian Criminal Justice History, Canadian Journal of Criminology, 41, 2, p.191-203.

Strange, C. (2001) The Undercurrents of Penal Culture: Punishment of the Body in MidTwentieth-Century Canada, Law and History Review, 19, 2, p.343-385.

Strange, C. and T. Loo (1997) Making Good: Law and Moral Regulation in Canada, 18671939, Toronto: University of Toronto Press.

Strange, C. and Loo, T. (2004) True Crime, True North: The Golden Age of Canadian Pulp Magazines, Vancouver: Raincoast Books.

Swainger, J. (2003) Police Culture in British Columbia and "Ordinary Duty" in the Peace River Country, 1910-39, in Backhouse, C. and Swainger, J. (Eds.), People and Place: Historical Influences on Legal Culture, Vancouver: UBC Press, p.198-223.

Walby, K. and Piché, J. (2015) Making Meaning Out of Punishment: Penitentiary, Prison, Jail, and Lock-Up Museums in Canada, Canadian Journal of Criminology \& Criminal Justice, 57,4, p.475-502.

Walker, B. (2010) Race on Trial: Black Defendants in Ontario's Criminal Courts, 1858-1958, Toronto: Osgoode Society for Canadian Legal History and University of Toronto Press.

Whitaker, R., Kealey, G.S. and Parnaby, A. (2012) Secret Service: Political Policing in Canada from the Fenians to Fortress America, Toronto: University of Toronto Press.

Wicken, W.C. (2012) The Colonization of Mi'kmaw Memory and History, 1794-1928: The King v. Gabriel Sylliboy, Toronto: University of Toronto Press. 